\title{
Web Application Development and Measurement Practices: A Survey of Jordanian Small Software Firms (JSSF)
}

\author{
Omar Tarawneh \\ Information Technology \\ Department \\ Al-Zahra College for \\ Women
}

\author{
Moath Husni \\ Information Technology \\ The World Islamic \\ Sciences and Education \\ University
}

\author{
Mejhem Al- \\ tarawneh
}

\author{
Serein Al-Ratrout \\ Information Technology \\ Department \\ Al-Zahra College for \\ Women
}

\begin{abstract}
The application of the development and measurement practices is very essential to acquire a high quality final product. This paper examines the extent of performing these practices in Jordanian small software firms (JSSF) as there is a lack of studies that conducted in the field. The results of this study were attained by8 performing three stages: first, collect data and analysis, second grouping practices using hierarchal clustering, and third, calculating the acceptance degree. Mean interval was used to determine the acceptance degree of each practice after that the overall average of acceptance is calculated for each cluster. The findings of this paper are fruitful to be used by the developers on the same field.
\end{abstract}

\section{Keywords}

Clustering, Measurement, Web Application Development.

\section{INTRODUCTION}

The web application development process should guarantee the quality of the final product, and avoid failures [1] [2].

A high percentage of web development companies around the globe are small size [3]. Small software firms refers to "any organization or company that has approximately 10 to 50 employees "[4][5][6]. One of the critical issues that faces these firms that they do not perform the best development practices $[8][35][36][37]$.

A best practice is "defined as a management or technical practices that should be performed to improve productivity, cost, schedule, quality, user satisfaction and predictability of cost and schedule" [10]. On the other hand, software measurement is used for controlling and managing any development project to reduce defects, rework and cycle time. Measurement process should be performed in parallel with the development process to get the desired quality [7] [9].

Numerous researches that conducted on the web application development field show that there is an absence of deploying the web application development best practices. Furthermore, so far there is a lack of studies that investigated the web development and measurement practices [11].

The greater part of the Jordanian software firms are considered small and the government still has little information about these firms' characteristics [8]. Therefore, this study conducted to examine the extent of performing the web application development and measurement practices in JSSF. The results demonstrate that there is an absence of performing the best development and measurement in JSSF. This paper is categorized into five sections: introduction, related studies, methodology, findings and conclusion.

\section{RELATED STUDIES}

Many studies conducted in the field in order to address the application of the development best practices. The most recent and related to this study are [15][11][26][8][37]. The results of the study that conducted in [15] showed that there is a necessity to perform the web application development best practices. In addition, the survey also illustrated that the attention of performing product quality measurement is low. Likewise, the greatest part of the Australian small software firms failed to perform the development best practices [11]. Furthermore, this study focused the development and management practices and ignored the measurement practices. The study that presented in [26] also indicated that a greater part of the small software firms in New Zealand despise the using of any development methods or practices. Another study conducted by [8] showed that the degree of performing web application development practices in the JSSF was found very low. In addition, this study did not mention anything about measurement practices. The last study conducted in Malaysia to examine the agile development practices in small software firms [37]. This study emphasizes on the development and neglects the measurement practices.

Based on the related studies, it is obvious that so far the both development and measurement practices for web application is not investigated. Therefore, it is important to examine the extent of performing the web applications development and measurement practices in JSSF.

\section{METHODOLOGY}

The results of this paper were attained by performing three stages: data collection and analysis, hierarchal clustering and acceptance degree calculation as shown in Fig 1.

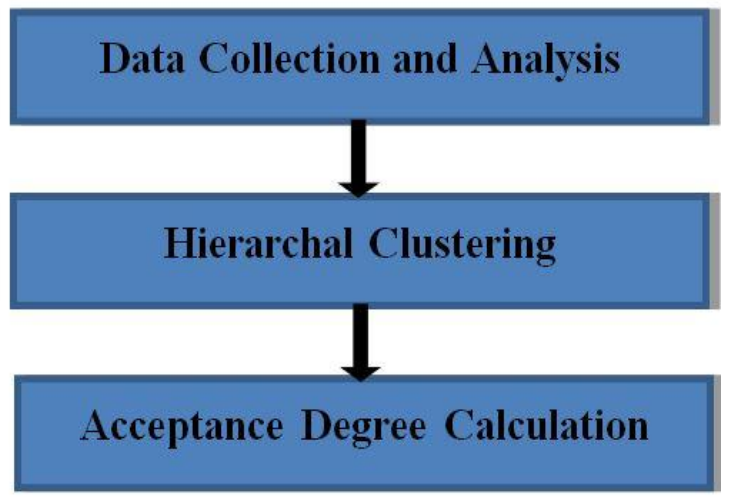

Fig 1: Methodology 


\subsection{Data collection and analysis}

Two activities were performed in this stage, namely: questionnaire design, data collection and data analysis. Questionnaire was designed in four sections based on three related studies [8][15][16]. However, The discussion his paper's focuses only on the section of web application development and measurement practices.

The questionnaire was validated using construct and content validity. The construct validity was performed by interviewing three expert developers. The selected developers have more than five years of experience in the field. A list of questions were presented to the experts to ensure the correctness, completeness and readability of the questionnaire.

The experts answered the questionnaire and found the questions correct, complete and readable. The feedback that was provided by the experts impacted minor modifications on the questionnaire.

A pilot study was conducted to ensure the content validity. The aim of the pilot study is to examine the answer time and the understandability of the questions. Twenty three JSSF participated in this pilot study. The results of the pilot study that were presented in [24][25] showed that respondents were capable to answer the questions without exceeding the specified time.

The respondents of this study are the developers and managers of JSSF. Accordingly, seventy five respondents were selected randomly. The data were collected using Mail questionnaire and interviews. Table 1 shows the list of questions related to practices and the corresponding variable names.

Table 1. Practices and variable names

\begin{tabular}{|c|c|c|}
\hline No & Practices & Variable \\
\hline 1 & $\begin{array}{c}\text { Does the process handle the time } \\
\text { pressure? }\end{array}$ & D1 \\
\hline 2 & $\begin{array}{l}\text { Does the development team understand } \\
\text { their roles and responsibilities based on } \\
\text { the development process used? }\end{array}$ & D2 \\
\hline 3 & $\begin{array}{l}\text { Minimum design and quick prototype are } \\
\text { performed by the development team. }\end{array}$ & D3 \\
\hline 4 & $\begin{array}{l}\text { Does each project has a nominated web } \\
\text { project manager? }\end{array}$ & D4 \\
\hline 5 & $\begin{array}{l}\text { The project plan includes budget } \\
\text { estimation. }\end{array}$ & D5 \\
\hline 6 & $\begin{array}{l}\text { The direct resources of requirements are } \\
\text { user or and the manager. }\end{array}$ & D6 \\
\hline 7 & $\begin{array}{l}\text { Is the web design use any design } \\
\text { notations? }\end{array}$ & D7 \\
\hline 8 & $\begin{array}{l}\text { The testing activity is carried out based } \\
\text { on the requirement specifications. }\end{array}$ & D8 \\
\hline 9 & $\begin{array}{l}\text { The testing activity is performed by the } \\
\text { development team. }\end{array}$ & D9 \\
\hline 10 & $\begin{array}{l}\text { Do the developers pay attention to the } \\
\text { quality characteristics such as usability } \\
\text { and user interface? }\end{array}$ & D10 \\
\hline 11 & $\begin{array}{l}\text { Is the software quality assurance team, } \\
\text { guiding the testing activity? }\end{array}$ & D11 \\
\hline
\end{tabular}

\begin{tabular}{|c|c|c|}
\hline 12 & $\begin{array}{l}\text { Is there a documented procedure for } \\
\text { dealing with volatile requirements? }\end{array}$ & D12 \\
\hline 13 & $\begin{array}{l}\text { Is a change control function established } \\
\text { for each web project? }\end{array}$ & D13 \\
\hline 14 & $\begin{array}{c}\text { Do your company use size measures } \\
\text { (such as "Lines of Source Code", function } \\
\text { points) to be used for productivity } \\
\text { measures? }\end{array}$ & D14 \\
\hline 15 & $\begin{array}{l}\text { Is a formal procedure used to produce the } \\
\text { web development effort, schedule, and } \\
\text { cost estimates? }\end{array}$ & D15 \\
\hline 16 & $\begin{array}{l}\text { Is there a required training program for } \\
\text { all newly-appointed web managers? }\end{array}$ & D16 \\
\hline 17 & $\begin{array}{l}\text { Is there a procedure for maintaining } \\
\text { awareness of the state-of-the-art in case } \\
\text { of web engineering technology? }\end{array}$ & D17 \\
\hline
\end{tabular}

\subsection{Hierarchal clustering}

Hierarchal clustering is a method used for grouping variables into homogeneous clusters[22][23]. Besides hierarchal clustering, factor analysis can be used for grouping variables. However, factor analysis is appropriate for a large data sample [20][21]. Therefore, hierarchal clustering is used to group the practices in this study. The process of clustering starts at the point when each cluster cluster contains one practice. Then, clusters are progressively joined until the foreseen cluster structure is acquired [21][27].

Wards technique is widely used in hierarchal clustering. This technique was chosen as it determines the correlations among the clusters based on the mean value that was attained from respondents' answers. The result of the hierarchal clustering represented in Fig 2. Each oval in the figure represents one cluster. The seventeen practices are grouped into seven clusters. Cluster 1 requirements practices. Cluster 2 quality practices. Cluster 3 measurement practices. Cluster 4 design practices. Cluster 5. Management practices. Cluster 6 process practices. Finally, Cluster 7 testing practices.

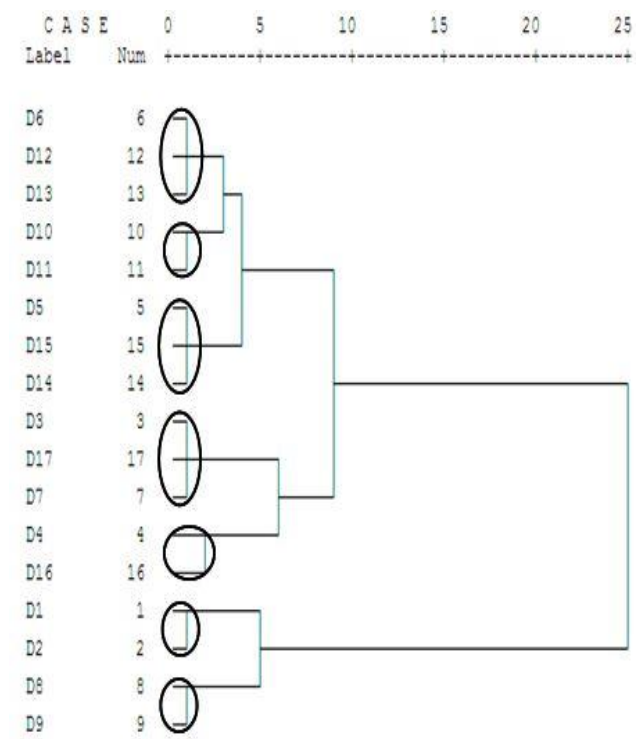

Fig 2: The clusters. 


\subsection{Acceptance degree calculation}

During this stage, the mean value for each practice is used to calculate the acceptance degree. Five Likert scales were used to describe the acceptance degree. The value 1 represents strongly disagree and the value 5 represents strongly agree.

The results were attained by calculating the mean score and choosing the appropriate interval that represent the actual mean which specifies the practices' applicability. The interval was calculated using (Eq (1)).

Appropriate interval $=($ number of scales -1$) /$ number of scales - Eq(1)

Appropriate interval for the study $=(4 / 5)=0.8$

The mean interval and acceptance degree representation is shown in Table 2.

Table 2. Internal representations for the acceptance degree

\begin{tabular}{|c|c|}
\hline Mean interval & Acceptance Degree \\
\hline From 1 to 1.80 & Strongly Disagree \\
\hline From 1.81 to 2.60 & Disagree \\
\hline From 2.61 to 3.40 & Neutral \\
\hline From 3.41 to 4.20 & Agree \\
\hline From 4.21 to 5 & Strongly Agree \\
\hline
\end{tabular}

\section{FINDINGS}

The results of this section are presented based on the acceptance degree calculation.

Each practice in any cluster has a mean value. The acceptance degree was intended by matching the mean value with the corresponding interval value in Table 2. Tables 3 to Table 9 show the mean value and acceptance degree for all clusters (Cluster 1 to 7 ).

Table 3. Requirement Practices (cluster 1)

\begin{tabular}{|c|c|c|}
\hline Requirements Practices & Mean Value & $\begin{array}{c}\text { Acceptance } \\
\text { Degree }\end{array}$ \\
\hline (D6) & 2.16 & Disagree \\
\hline (D12) & 2.16 & Disagree \\
\hline (D13) & 2.17 & Disagree \\
\hline
\end{tabular}

Cluster 1 Requirement Practices: these practices are very essential as they clarify the way of collecting requirements inside the organizations and by whom [15][19]. Table 3 shows that all the practices in this cluster have mean interval values between 1.81 and 2.60, indicating that JSSF did not perform the best requirements practices.

Table 4. Quality Practices (cluster 2)

\begin{tabular}{|c|c|c|}
\hline Quality Practices & $\begin{array}{c}\text { Mean } \\
\text { Value }\end{array}$ & $\begin{array}{c}\text { Acceptance } \\
\text { Degree }\end{array}$ \\
\hline (D10) & 1.99 & Disagree \\
\hline (D11) & 1.97 & Disagree \\
\hline
\end{tabular}

Cluster 2 Quality Practices: this cluster is related to the quality management and quality assurance [28][29]. Results in Table 4 show that most developers of the JSSF are incurious of applying the quality management and assurance practices during the development process.

Table 5. Measurement Practices (cluster 3)

\begin{tabular}{|c|c|c|}
\hline Measurement Practices & $\begin{array}{c}\text { Mean } \\
\text { Value }\end{array}$ & $\begin{array}{c}\text { Acceptance } \\
\text { Degree }\end{array}$ \\
\hline (D5) & 1.85 & Disagree \\
\hline (D14) & 1.85 & Disagree \\
\hline (D15) & 1.83 & Disagree \\
\hline
\end{tabular}

Cluster 3 Measurement Practices: this cluster focused on the measurement method and metrics that is used to measure the budget, size, effort and schedule[9]. All practices in cluster 3 have the same acceptance degree (disagree). This means that the developers in JSSF do not perform any measurement method or metrics during the web application development process.

Table 6. Design Practices (cluster 4)

\begin{tabular}{|c|c|c|}
\hline Design Practices & $\begin{array}{c}\text { Mean } \\
\text { Value }\end{array}$ & $\begin{array}{c}\text { Acceptance } \\
\text { Degree }\end{array}$ \\
\hline (D3) & 2.44 & Disagree \\
\hline (D7) & 2.47 & Disagree \\
\hline (D17) & 2.40 & Disagree \\
\hline
\end{tabular}

Cluster 4 Design Practices: design is a very important activity that supports the developers speed up the development process and makes it usable [30][31]. As presented in Table 6 it is obvious that the developers in JSSF are currently using a complicated and time-wasting design practices during the development process.

Table 7. Management Practices (cluster 5)

\begin{tabular}{|c|c|c|}
\hline Management Practices & $\begin{array}{c}\text { Mean } \\
\text { Value }\end{array}$ & $\begin{array}{c}\text { Acceptance } \\
\text { Degree }\end{array}$ \\
\hline (D4) & 2.64 & Neutral \\
\hline (D16) & 2.31 & Disagree \\
\hline
\end{tabular}

Cluster 5 Management Practices: this cluster of practices helps to make the process activities, roles and outcomes clear and manageable [32]. Results in Table 7 demonstrate that there is no training program for the chosen manager of each project.

Table 8. Process Practices (cluster 6)

\begin{tabular}{|c|c|c|}
\hline Process Practices & $\begin{array}{c}\text { Mean } \\
\text { Value }\end{array}$ & $\begin{array}{c}\text { Acceptance } \\
\text { Degree }\end{array}$ \\
\hline (D1) & 3.53 & Agree \\
\hline (D2) & 3.52 & Agree \\
\hline
\end{tabular}

Cluster 6 Process practices: this cluster of practices is important to determine whether the used development process is capable to deal with time constraint and if the roles and responsibilities of the development team are clearly defined 
[15][19]. Results in Table 8 show that JSSF developers are able to perform the process practices by scoring a high acceptance degree (agree).

Table 9. Testing Practices (cluster 7)

\begin{tabular}{|c|c|c|}
\hline Testing practices & $\begin{array}{c}\text { Mean } \\
\text { Value }\end{array}$ & $\begin{array}{c}\text { Acceptance } \\
\text { Degree }\end{array}$ \\
\hline (D8) & 3.35 & Neutral \\
\hline (D9) & 3.53 & Agree \\
\hline
\end{tabular}

Cluster 7 Testing Practices: testing activity is very essential as it includes the practices for evaluating web application [33][34]. Table 9 shows that developers test web applications based on the requirements specification. It was also found that the testing team is not separated from the development team, which considered impractical.

Based on the results attained from Table 3 to Table 9, it is clear that the degree of performing the important development and measurement practices by the JSSF is very low. The overall results of this study are shown in Table 10 which represents the acceptance degree of each cluster.

Table 10. Overall Results

\begin{tabular}{|c|c|}
\hline Practices cluster & $\begin{array}{c}\text { Overall Acceptance } \\
\text { Degree }\end{array}$ \\
\hline Cluster 1 & Disagree \\
\hline Cluster 2 & Disagree \\
\hline Cluster 3 & Disagree \\
\hline Cluster 4 & Disagree \\
\hline Cluster 5 & Disagree \\
\hline Cluster 6 & Agree \\
\hline Cluster 7 & Agree \\
\hline
\end{tabular}

Based on Table 10, five clusters are not performed by the JSSF. These clusters of practices are: requirements, quality, measurement, design, and management. These practices are viewed as critical and essential to get high quality web applications. Therefore, the practitioners in JSSF should pay more attention to integrate these important practices with their development process to improve the web application quality.

\section{CONCLUSION}

This paper investigates the extent of using the web application development and measurement practices by the JSSF. Seven clusters of practices are identified using the hierarchal clustering method. The clusters are: requirements, quality, measurement, design, management, development process and testing.

After calculating the overall acceptance degree of each cluster, the results indicated that five among seven clusters of practices are not performed by the JSSF, namely: requirements, quality, measurement, design and testing practices. These clusters are very essential to improve web application quality and help the team to reduce costs, efforts and development life cycle time.

In general, it can be concluded that there is an absence of performing a set of important development and measurement practices during the development process. Therefore, the JSSF can use the results of this study to improve their development process and integrate it with the suitable measurement mechanism to get a high quality web application.

\section{REFERENCES}

[1] J. Conallen, "Modeling Web application architectures with UML," Communications of the ACM, vol. 42, pp. 63-70, 1999.

[2] D. Rodriguez, R. Harrison, and M. Satpathy, "A generic model and tool support for assessing and improving Web processes," in Proc. IEEE Symposium, 2002, pp. 141151.

[3] I. Richardson and C. Gresse von Wangenheim, "Guest Editors' Introduction: Why are Small Software Organizations Different?," Software, IEEE, vol. 24, pp. 18-22, 2007.

[4] M. E. Fayad, M. Laitinen, and R. P. Ward, "Thinking objectively: software engineering in the small," Communications of the ACM, vol. 43, pp. 115-118, 2000.

[5] C. Hofer, "Software development in Austria: results of an empirical study among small and very small enterprises,"in Proc. (EUROMICRO’02), 2002. pp. 361366.

[6] C. Y. Laporte, A. Renault, J. Desharnais, N. Habra, M. Abou El Fattah, and J. Bamba, "Initiating software process improvement in small enterprises: Experiment with micro-evaluation framework,". In Proc. SWDCREK, 2005, pp. 153-163.

[7] J. McCurley, D. Zubrow, and C. Dekkers, "Measures and measurement for secure software development," Carnegie Mellon University Build Security In, 2008.

[8] A. El Sheikh and H. Tarawneh, "A survey of web engineering practice in small Jordanian web development firms," .in Proc. ACM SIGSOFT, 2007, pp. 481-490.

[9] R. kettelerij. "Designing a measurement program for software development projects", master thesis 2006, Faculty of Science, University of Amsterdam, www.science.uva.nl.

[10] D. H. Withers, "Software engineering best practices applied to the modeling process," Proceedings of the Winter Simulation Conference, Orlando, 2000, pp. 432439 vol. 1.

[11] Cater-Steel, "An evaluation of software development practice and assessment-based process improvement in small software development firms", PhD thesis, Griffith University, December 2004

[12] M. Azuma and D. Mole, "Software management practice and metrics in the european community and japan: Some results of a survey," Journal of Systems and Software, vol. 26, pp. 5-18, 1994.

[13] J. D. Blackburn, G. D. Scudder, and L. N. Van Wassenhove, "Improving speed and productivity of software development: a global survey of software developers," Software Engineering, IEEE Transactions on, vol. 22, no.12, pp. 875-885, 1996.

[14] Y. Yasrina, "The Use of Information System Development Methodology in Malaysia". Jurnal 
Antarabangsa (teknologi maklumat), vol. 2, no. 2002, pp.15-34

[15] A. McDonald and R. Welland, "A survey of web engineering in practice," Department of Computing Science Technical Report R-2001-79, University of Glasgow, Scotland, vol. 1, 2001

[16] F. Baharom, A. Deraman, and A. Hamdan, "A Survey on the Current Practices of Software Development Process in Malaysia," Journal of ICT, vol. 4, pp. 57-76, 2006.

[17] "Introduction to Survey Design and Delivery," (NOAA), Ed., ed. Charleston: NOAA Coastal Services Center, 2007.

[18] D. Nachmias, C. Nachmias, and C. F. Nachmias, Research methods in the social sciences: 5th Edition, Aenold a member of the Hodder Headline Group London, 1996.

[19] W. Huang, R. Li, C. Maple, H. Yang, D. Foskett, and V. Cleaver, "Web Application Development Lifecycle for Small Medium-Sized Enterprises (SMEs)," in Proc of The Eighth International Conference on Quality Software ,2008, pp. 247-252.

[20] J. Pallant, SPSS Survival Manual: A Step by Step Guide to Data Analysis Using SPSS for Windows Version 15: Open University Press, 2007.

[21] Tabachnick, B., \& Fidell, L. "Using multivariate analysis." 5th Edition Allyn \& Bacon; Needham Heights MA. 2007.

[22] C. Chatfield and A. J. Collins, Introduction to multivariate analysis vol. 166: Chapman \& Hall/CRC,London, 1990.

[23] Johnson, R.A. and Wichern, D.W. Applied Multivariate Statistical Analysis. Prentice-Hall of India Private Limited. 4th edition, 1996.

[24] F. Ahmad, F. Baharom and M. Husni, "Investigating the Awareness of Applying the Important Web Application Development and Measurement Practices in Small Software Firms," vol. 3, no.6, pp. 147-158, 2011

[25] F. Ahmad, F. Baharom and M. Husni, "Current Web Application Development and Measurement Practices for Small Software Firms" vol. 9, no.2, pp. 125-129, 2012

[26] D. Kirk and E. Tempero, "Software Development Practices in New Zealand". In Proc of the19th AsiaPacific Software Engineering Conference (APSEC), 2012, pp. 386-395
[27] T. Dingsøyr, S. Nerur, V. Balijepally, N. Brede Moe, A decade of agile methodologies: towards explaining agile software development, Journal of Systems and Software 85 (6) (2012) 1213-1221

[28] D. M. Owens and D. Khazanchi, "Software Quality Assurance," Handbook of Research on Technology Project Management, Planning, and Operations. ISBN, vol. 1965131010, 2009.

[29] Y. Wu and J. Offutt, "Modeling and testing web-based applications," GMU ISE Technical ISE-TR-02-08, 2002.

[30] M. Tarafdar and J. Zhang, "Determinants of reach and loyalty-a study of Website performance and implications for Website design," Journal of Computer Information Systems, vol. 48, no. 2, pp. 16-24, 2008.

[31] A. Ginige and S. Murugesan, "Web engineering: An introduction," MultiMedia, IEEE, vol. 8, pp. 14-18, 2001.

[32] A. Abran, P. Bourque, R. Dupuis, and J. W. Moore, Guide to the software engineering body of knowledgeSWEBOK: IEEE Press, 2001.

[33] S. Murugesan, Y. Deshpande, S. Hansen, and A. Ginige, "Web engineering: A new discipline for development of web-based systems," in Web Engineering, ed: Springer, 2001, pp. 3-13.

[34] A. Redouane, "Guidelines for Improving the Development of Web-Based Applications," in Proceedings of the Fourth International Workshop on Web Site Evolution (WSE'02), 2002, p. 93.

[35] E. Kouzari, V. C. Gerogiannis, I. Stamelos, and G. Kakarontzas, "Critical success factors and barriers for lightweight software process improvement in agile development: A literature review," 10th International Joint Conf. on Software Technologies (ICSOFT), vol. 1, pp. 1-9, July 2015.

[36] Moath Husni, Omar Tarawneh, Mejhem Al-tarawneh and Ali Naimat. The Compatibility and Conflict between XP Method and Level Two of CMMI-Dev1.2. International Journal of Computer Applications, vol.182, no. 20, pp. 5$11,2018$.

[37] Mohamed, Shafinah Farvin Packeer, Fauziah Baharom, and Aziz Deraman. "An exploratory study on agile based software development practices." International Journal of Software Engineering and its Applications, vol. 8, no. 5 (2014): 85-114 